\title{
Relationship with the European Union: Slovenia and Montenegro Compared
}

\author{
GORDANA DJUROVIC AND DAMJAN LAJH
}

\section{sciendo}

Politics in Central Europe (ISSN: 1801-3422)

Vol. 16, No. 3

DOI: $10.2478 /$ pce-2020-0030

\begin{abstract}
As part of former Yugoslavia and non-members of the Eastern Bloc, Slovenia and Montenegro enjoyed a special status and relationships with the European Communities (EC) before most other socialist countries. Economic and social interactions with the EC and its member states thus formed part of Slovenian and Montenegrin life even during socialism, particularly after Yugoslavia signed special agreements on trade relations with the EC in the 1970s and 1980s. In this respect, Europeanisation as 'practical' integration with the EC was closely linked with liberalisation processes concerning the economy, society and politics along with democratic transition processes that began in the late 1980s. When Slovenia joined the European Union (EU) in 2004 following a relatively smooth integration process, Montenegro was still holding EU candidate member status, after having officially started its accession negotiations in June 2012. The article analyses selected development and integration aspects of Slovenia and Montenegro, their relationship with the EU, together with their similarities and differences. The aim is to highlight developments in both countries and determine whether Slovenia, as an ex-Yugoslav republic and EU member since 2004, may serve as a good example for Montenegro to follow while pursuing European integration.
\end{abstract}

Keywords: European Union, Europeanisation, enlargement, Slovenia, Montenegro

\section{Introduction}

Europeanisation is generally associated with terms like innovation, modernisation or formation, and thus often used to describe several different phenomena and processes of change (Lajh 2005). It is hence no surprise that investigating Europeanisation processes has become popular in the area of former Yugoslavia, 
which has a distinct history, including how the European Union (EU) views the former socialist country. This area also has several outstanding issues in its relationship with the EU.

In all of the former Yugoslav republics, albeit under different conditions, the democratic transition started in the early 1990s when the republics all adopted new constitutions and held their first democratic and free elections (Fink Hafner - Lajh - Krašovec 2005). Except for Slovenia, the democratic transition in all the other former republics was largely initially postponed. The many reasons for this include (in)direct involvement in war, strong ethnic cleavages, and socio-economic factors. In the past, the Yugoslav state was very diverse and the region of former Yugoslavia remains that way today, both politically and socio-economically. As a result, Slovenia was the only former Yugoslav republic to join the EU on 1 May 2004, experiencing the Europeanisation process in various aspects of its political system and public policies. In contrast, all the other former Yugoslav republics saw delays in their democratic transition (see Ramet 2002). They were fighting for democratic survival more than confronting the task of completing European integration processes. In general, these delayed democratisation processes then exerted a negative influence on the development of market economies. Moreover, the other Yugoslav republics have had to meet additional criteria imposed later in the EU accession process. Above all, these criteria include cooperation with the International Court of Justice in The Hague, especially from countries heavily and directly involved in the Civil War (Lajh - Krašovec 2007).

When it comes to Europeanisation processes, the degree of adaptation depends on the 'goodness-of-fit' between the European-level arrangement and the domestic structures: the lower the compatibility (fit) between the new requirements on one hand, and national structures on the other, the greater the adaptational pressure (Risse - Cowles - Caporaso 2001: 6-7). Europeanisation processes thus 'require' various national actors to participate in the internalisation of EU norms and development of new identities. Satisfying these new requirements means changing actions, routines and even formal procedures (North 1990: 83), subject to the level of adaptational pressure. The different political arrangements in the EU mean the outcome is a very diverse pattern of problem-solving approaches and styles of organisation (Héritier 1999: 19-20) in both EU member and accession states. This internalisation (or adaptation) is thus not mechanical.

In light of these considerations, this article's main aims are to discuss how the respective relationships of Slovenia and Montenegro with the EU have developed and to highlight the biggest changes in the two countries. Ever since the dissolution of former Yugoslavia, both countries have been subjected to different modernisation processes. While Slovenia is already an EU member and has experienced the Europeanisation processes in various domains of its political system and public policies, Montenegro with EU-candidate-state 
status and 8 years of accession talks experience still faces many challenges with Europeanisation. Given the considerable differences in several aspects of political, social and economic life, even when taking the common history of Yugoslavia into account, our main research thesis is that we cannot expect Montenegro to be able to see Slovenia as a perfect model to follow in its own Europeanisation processes.

The article is divided into three major sections and proceeds as follows. The first section explains the special relations of former socialist Yugoslavia with the European Community. The second section considers Slovenia's evolving relationship with the EU. It begins by describing the key physiognomies of Slovenia's accession to the EU, i.e. a relatively smooth integration with only a few problems, marked by a strong pro-EU orientation of both the Slovenian political elite and the citizens after the country's independence. Then it focuses on the main challenges in the period of full EU membership, especially the financial and economic crisis. The third section analyses Montenegro's path to the EU from the perspectives of regaining independence and negotiating EU membership. Finally, the fourth section synthesises the overall findings and discusses the primary challenges and future positions of Slovenia and Montenegro within/towards the EU.

\section{Relationship of Former Socialist Yugoslavia with the European Community}

The first official contacts between the Socialist Federal Republic of Yugoslavia (SFRY) and the European Economic Community (EEC) were already made in 1962 but the complex negotiation process meant the SFRY-EEC Declaration on Relations was only adopted on 2 December 1967, leading to the establishing of diplomatic relations and appointment of the first Yugoslav Ambassador to the EEC on 16 September 1968 (Adamović 1988: 243-246). The Declaration was the first political act signed by the EEC in its previous practice with a socialist state, a legal framework for strengthening economic and political cooperation with Yugoslavia.

On 25 October 1962, the Yugoslav ambassador in Brussels, Vjekoslav Prpić, formally expressed to the European Commissioner for External Relations, Jean Rey, his government's desire to establish official contacts with a Commission delegation (ECHA 1986a: 1). The Six Council in December that year decided to meet the Yugoslavs' request in principle, without giving them any precise details as to when exploratory talks could start (ECHA 1986b: 1). However, the door was opened for the future negotiation and establishment of the first official framework for political and economic cooperation. Two rounds of exploratory conversations took place in Brussels in January and May 1965. These talks concentrated on three main subjects: contemporary trade relations between the 
Community and Yugoslavia, contractual relations between Yugoslavia and the EEC member states, and the future effect of European integration on Yugoslav exports of agricultural and industrial products (ECHA 1980: 1). After a few breaks, the conclusion of the GATT Kennedy Round (1964-1967) in Geneva allowed the parties to re-activate their bilateral relations. This was the end of the mentioned procedure which began in Brussels in January 1965. After three phases of negotiation, the two sides signed their first non-preferential trade agreement in 1968 granting each other the status of most-favoured nation. The Agreement came into force on 1 May 1970 and provided not only certain concessions for agricultural and industrial products but also the legal framework for the economic relations between the Community and Yugoslavia (Commission of the European Communities 1970: 2). A joint committee was established to supervise the smooth running of the agreement. It was the start of the SFRY's economic integration steps towards the Community.

After the 1970 agreement, the EEC's Yugoslav policy was characterised by continuity. A second trade agreement was signed in June 1973, providing for the further liberalisation of trade and an adjustment of the EEC's external tariffs to ensure free access for Yugoslav exports of agricultural products into the Community. A third trade agreement was signed in February 1980, with the main goal to reduce the deficit (USD 3 billion in 1979) in the Yugoslav balance of payments vis-à-vis the Community. The agreement therefore represented an attempt to restrict the access of Yugoslav products to the Community markets (trade part) and foster cooperation in several crucial areas like industry, technology and investment promotion (financial part and cooperation). Yugoslavia was to be granted ECU 200 million over a 5-year period (USD 1.44 million in February 1980) in the form of loans from the European Investment Bank with normal market conditions. The third agreement was signed for an indefinite duration with a trade segment review every 5 years (European Community 1980: 1-2). The other cooperation fields were labour mobility, industry, energy, scientific and technological research, agriculture, transport, tourism, the environment, and fisheries. Both Yugoslavia and the EEC saw this cooperation agreement as a political landmark for future relations (Zaccaria 2016: 163-164).

As the Community enlarged and deepened its common policies, economic cooperation strengthened. On 17 December 1990, the SFRY also joined the first Central and Eastern European Community Programme (PHARE). At the end of the 1980s, the SFRY was strongly reliant on economic relations with the European Communities, yet upcoming events in the long term were delaying any form of integration. Further cooperation became much more difficult as Yugoslavia entered a period of economic, political and social crisis which ultimately led to the country's disintegration (Obadić 2014: 344).

When considering EU accession or candidate states, adaptation pressures on different domains of the political system vary dramatically with respect to 
the level of institutional relationship with the EU. In this context, Lippert Umbach - Wessels (2001: 985) talk about five steps in Europeanisation. In the pre-phase of Europeanisation, the initial contacts between applicant states and the EU are (re-)established. In the first phase of Europeanisation, the European or Accession Agreement is signed, with this providing the backbone of (future) institutional relations. The second phase embraces the pre-accession period, which leads to the first elementary institutional adaptations, particularly with regard to the efficient coordination of European affairs on the national level. The third phase of Europeanisation includes the negotiation process in which either incremental or radical changes in individual policy fields first occur. The last phase of Europeanisation embraces the period of membership (Lippert Umbach - Wessels 2001: 985-1000).

The main preconditions for EU membership are respect for the principles of freedom, democracy, human rights, fundamental freedoms, and the rule of law. In this way, to approach the EU a country must fulfil economic and political conditions known as the Copenhagen Criteria, according to which a candidate country must: (a) be a stable democracy, respect human rights and the rule of law and protect minorities; (b) have a working market economy; and (c) adopt the common rules, standards and policies which make up the body of EU law (Jacobsen 1997: 1). When considering the post-Yugoslav region, after independence only Slovenia followed the Central and Eastern European 'natural' pattern and, according to Lippert - Umbach - Wessels (2001: 985), had completed all five steps of Europeanisation, later to be followed only by Croatia. However, at this point at least two more important facts must be mentioned. Besides the noted preconditions for not only EU membership but for building up deeper institutional relations, practically all the other former Yugoslav republics were meeting the additional criteria for EU accession. Among these criteria, cooperation with the International Court of Justice in The Hague is especially prominent. Second, in most other post-Yugoslav republics, the EU has not been the sole "institutional mentor" (Ágh 2003: 117) since this role has also very much been in the hands of the wider international community.

As part of former Yugoslavia and non-members of the Eastern Bloc, Slovenia and Montenegro held a special status and relations with the EEC before most other socialist countries. Economic and social interactions with the EEC and its member states thus formed part of Slovenian and Montenegrin life even during socialist times, particularly after Yugoslavia signed special agreements on trade relations with the EC in the 1970s and 1980s (Fink Hafner - Lajh 2003). In this respect, Europeanisation as 'practical' integration with the EEC was closely linked to the liberalisation processes concerned with the economy, society and politics as well as to the democratic transition processes that started in the late 1980s. 


\section{Slovenia's Path to the EU: From Best Student in the Class to the European Periphery?}

\section{Slovenian Accession and the Copenhagen Learning Process}

Slovenia's relationship with the EU is as long as the history of the country's independence. The process of Slovenia's transition from a socialist political system within Yugoslavia to independence in the late 1980s and early 1990s was already characterised by the ambition to join the EU with the aim to become an economically successful and internationally recognised democratic country (Lajh 2012). In this sense, EU membership was defined as a national project even before Slovenia's formal independence. The reformed former Slovenian League of Communists even adopted a document entitled "Europe now - for the European quality of living" for its congress in autumn 1989 and used the slogan "Europe Now!" at the first multi-party and democratic elections in 1990 (Balažic 2002). Other political parties also included EU integration in their electoral programmes for the first multiparty elections (Krašovec - Lajh 2009). Fink-Hafner even claims that Europeanisation had "become a kind of substitute for the old ideology" (Fink Hafner 1999). In 1991, the ambition to become an EU member was formally declared in the Basis of Slovenian Foreign Policy (Fink Hafner - Lajh 2005). The whole EU accession period in Slovenia was marked by a broad consensus among the political elite on the process of joining the EU. All relevant Slovenian political parties generally agreed that Slovenia should become an EU member. Except for one parliamentary political party, the Slovenian National Party, no parliamentary political party publicly opposed this aim. Moreover, as early as in 1997, practically all parliamentary parties - again with the exception of the Slovenian National Party - and the representatives of the Hungarian and Italian minorities, irrespective of their other differences and conflicts, decided to sign an Agreement on Cooperation in the Accession Process with the EU (Fink Hafner - Lajh 2005).

Despite the general support for European integration, the process of joining demanded certain adaptations that the Slovenians were not too happy to make. The three most salient issues were: (1) the 'Spanish Compromise', which gave foreigners the right to buy Slovenian real estate and triggered a fear, of especially among Slovenians living close to the border, that the former 'occupier' would again occupy the land; (2) the issue of closing down the duty-free shops located on the border with Italian and Austrian, where foreigners used to buy luxury goods like cigarettes, alcohol and cosmetics; and (3) a transition period for the free movement of labour (Krašovec - Kustec Lipicer 2008). Unsettled issues connected with EU membership triggered a decrease in public support and slowly saw some Euroscepticism emerge among the Slovenian public. In addition, in 2002 it was announced that due to its stable economy Slovenia 
would be joining the EU as a net contributor and be paying more funds into the EU than it would be receiving (Nations in Transit 2003). Still, even after minor problems with the country's accession to the EU, despite these rumours of Slovenia being a net contributor the lion's share of the public remained in support of Slovenia's EU membership (Lajh 2012). This was confirmed at a referendum on EU accession (see Krašovec - Lajh 2004), which finally showed there was no serious opposition to accession in Slovenia. In March 2003, 60.4\% of the electorate participated in the referendum, with almost $90 \%$ percent of voters being in support of joining the EU. This very high support for the EU was probably also a result of the Slovenian Government's "Slovenia at home in Europe" campaign (Fink Hafner - Deželan 2016: 476). On the same day, 66\% of voters also supported a referendum to join NATO.

During the process of Slovenia's accession to the EU, the national political system needed to adapt to the new circumstances. Fink Hafner and Lajh (2005) demonstrated that national institutions, processes, traditions and politico-cultural context remained flexible and pragmatic in their adaptations. No radical change was made; instead, political structures only rearranged their setup to meet the demands of the accession process. In October 1995, special units for handling EU affairs were established within most ministries and other governmental bodies. EU tasks were thereby dispersed rather than concentrated in a special unit with an EU-knowledgeable elite (Fink Hafner 2007). The coordination of European affairs began at the end of 1997, starting with establishing the Government Office for European Affairs (GOEA), led by a minister without portfolio that took on management and coordination of the Slovenian accession process, the forming of the Negotiating Team of the Republic of Slovenia for Accession to the EU, and inter-sectoral working groups which included representatives of ministries and relevant institutions to prepare the negotiating positions. However, the Ministry of Foreign Affairs remained the chief negotiator, while the Prime Minister led the coordination of managing EU affairs (Fink Hafner 2007: 818-819). At the end of the negotiations in February 2003, the Minister for EU Affairs was created in the first year of membership and the GOEA was reformed and institutionalised to become the central coordinating unit (Fink Hafner 2007).

Slovenia joined the EU on 1 May 2004. Along with the broad agreement on EU membership, other EU-related issues from 2004 onwards enjoyed general support and were seen as national projects, including introduction of the common currency the euro, joining the Schengen Area and conducting the first Slovenian Presidency of the Council of the EU (Krašovec - Lajh 2009). This attitude to the EU whereby parties agreed not to take advantage of inter-party competition on EU matters characterises the first period of membership until the country held the EU Presidency. In May 2007, on the basis of a party agreement the parliamentary parties even signed the "Agreement on the co-operation 
of political parties, the group of unconnected deputies and representatives of national minorities in the National Assembly of the Republic of Slovenia for the successful preparation and implementation of the Presidency of the EU". This agreement was informally known as an "agreement on 'non-attacking' the government in the period of holding the EU Presidency" (Fink Hafner - Lajh 2008). However, two parties in opposition - Liberal Democracy of Slovenia and Slovenian National Party- did not sign the agreement (Krašovec - Lajh 2009).

\section{Economic Crisis and Dropping Trust in the EU}

The next few years of Slovenian EU membership began with the global financial and economic crisis that not only impacted the EU but also the Slovenia-EU relationship. After all, Slovenia was hit particularly hard by the crisis with poor public finance conditions and escalating public borrowing. These economic and financial crises strengthened feelings of Euroscepticism among Slovenians.

In 2012, Slovenia started to struggle with a deepening economic crisis, rising public debt and a collapsing banking sector. The government was under European Commission pressure to accept certain austerity measures and reforms connected with managing the consequences of the financial crisis, attracting some negative attitudes regarding the EU. Austerity measures were adopted in early 2012 but these were still unable to reassure the major credit agencies, which doubted Slovenia could save its state-owned banks. In the end, this triggered predictions that Slovenia would be the sixth EU member state to require a bailout (Lajh 2013). In March 2012, EU member states that had adopted the euro agreed to the golden fiscal rule and agreed that their country's expenditures would not exceed their revenues. The Slovenian Government suggested inscribing the fiscal rule in the Constitution, which the new government of Alenka Bratušek took care of in 2013. Following the recommendations of the European Commission, the new government also adopted a stability programme on fiscal consolidation and national reform programmes containing policies to promote growth such as raising the level of value-added tax (Lajh 2014). Prime Minister Alenka Bratušek wished to convince the international public that Slovenia would not become the next EU member to request a bailout. In an unfortunate interview with $\mathrm{CNN}$, she repeatedly declared "we do not need money, we need time". Ultimately, Slovenia managed to avoid an international bailout with a series of austerity measures and structural reforms. In June 2015, the European Commission finally allowed Slovenia to leave the EU's excessive deficit procedure (Lovec 2017).

Much of the period since 2014 has also been marked by tensions between Slovenia and Croatia concerning their disputed border, with both turning to EU institutions for support. Slovenia has relied heavily on an international arbitration judgment to finally resolve the border issues with Croatia that have 
strained the Croatia-Slovenia relationship for several years. Slovenia even vetoed Croatia's EU accession negotiations (Lajh - Krašovec 2010) and is currently expressing an interest to block Croatia's entry to both the Schengen Area and the OECD due to Croatia's apparent lack of respect for international law. In 2015, the Croatian Parliament and Government decided to abandon the arbitration after a Croatian newspaper disclosed a secretly recorded conversation between a member of the Slovenian delegation and the arbitrator on the panel (Haček 2016). Despite this unfortunate event, Slovenia insists the arbitration judgment should be enforced while Croatia insists the EU should not play any role in resolving the border issue. In June 2017, the Permanent Court of Arbitration announced its ruling, designating three-quarters of the Piran Gulf to Slovenia and establishing a easement between Slovenia and international seas (Lovec 2018). The court judgment was not implemented within the estimated 6-month period. The Slovenian public also strongly condemned the Slovenian European Commissioner for Transport Violeta Bulc for insufficiently representing Slovenia's interests at meetings of the College of Commissioners regarding enforcement of the arbitration judgment.

The bilateral relations between Slovenia and Croatia took another blow during the migration crisis between October 2015 and March 2016 when almost 480,000 migrants crossed the Schengen border between Croatia and Slovenia. Slovenia accused Croatia of not respecting the EU's rules and procedures and encouraging more people to cross the border than agreed. When EU assistance at the border and extra EU funds finally arrived, the situation slowly started to improve and normalise as the Western Balkans corridor was closed (Haček 2016; Lovec 2017). Yet civil society remains critical of the EU's asylum and migration policy that has been clearly unable to cope with the crisis. With the controls being established on the inner border between Slovenia and Austria due to the possibility of illegal migrations, Slovenia faces another unpleasant experience in the EU. Slovenian politicians and MEPs have tried in conversations with the EU to negotiate an end to these border controls, but have thus far been unsuccessful.

Despite the slight rise of Euroscepticism during Slovenia's EU membership, the EU still enjoys a relatively positive image among Slovenians. The share of Slovenians with a very negative image of the EU is consistently below $5 \%$ (Krašovec - Lajh 2020). Dissatisfaction with the EU was at its highest in 2013 and 2014 during the economic crisis. Further, Slovenian politicians in the EU, such as former Slovenian Commissioner Violeta Bulc and Slovenian MEPs, have constantly been evaluated as the most popular by the Slovenian public. However, before the 2019 EP elections the media published various ratings of the work of Slovenian politicians in the EU where they performed worse than their colleagues. Violeta Bulc was one of the worst-rated European Commissioners, coming in $21^{\text {st }}$ place among 28 (Burson Cohn - Wolfe 2019). Slovenian MEPs 
were similarly unsuccessful; except for Tanja Fajon who was ranked in $49^{\text {th }}$ place among 751 MEPs, the rest were ranked between places 378 and 531 (MEPranking 2018). Slovenia's role in the EU was also judged by the Slovenian public when the media revealed that the Slovenian Government was ranked in last place $\left(25^{\text {th }}\right)$ alongside the neighbouring Croatia, Latvia and Malta with regard to the country's common influence on European politics and policies. Slovenia was only reasonably active in the policy field of bigger European integration (European Council on Foreign Relations 2018).

The Slovenian Government views the second Presidency of the Council of the EU in 2021 as an important milestone. In February 2018, a working group led by the Prime Minister to manage staff and finance during the presidency was established. The document "Special governmental project: Presidency of the Republic of Slovenia of the Council of the EU" was published in March 2019, where the government states in the introduction that Slovenia's reputation among the EU members and beyond will depend on success with project (Zorman Macura 2019). Such statements already give the impression that Slovenia will again concentrate on the organisational aspects of the presidency and forget its own preferences regarding EU policymaking. Slovenia will once more preside in a trio with Germany and Portugal. It is anticipated that developing the European perspective on the Western Balkan countries will again be a priority topic for Slovenia.

\section{Montenegro's Path to the EU: Regaining Independence and Negotiating on EU Membership}

\section{Regional approach and the Enlargement Plus criteria}

In the early 1990s, the state of Yugoslavia began to disintegrate, a process still not fully resolved, leading to a series of civil wars in the Western Balkans. After the destructive events of in the 1990s, the Western Balkan countries (ex-Yugoslavia, without Slovenia, plus Albania) started on their political and economic rehabilitation and reconciliation. Balkan reconstruction became a pressing issue for the international community following the wars of the 1990s (Montanari 2005: 82). The geopolitical landscape in the Western Balkans was not as uniform or homogenous as the umbrella term may suggest. The region christened "the Western Balkans" by Brussels in 1998 is basically a space squeezed between EU member states (the EU's only internal neighbouring region), supposedly destined to join them but without a clear accession timetable (Štiks 2011: 123). The EU played a key role in the region's rebuilding efforts by influencing and shaping the nature of the state, society and foreign relations by utilising the prospect of EU membership as a vital tool for exerting its influence in the region. As the EU started to pursue a revised enlargement strategy 
with integrative elements, the region has gradually been transformed from its "Balkanised" form into a "Europeanised" one. Yet, the regional approach failed to provide the prospect of membership as the major incentive for conditionality and did not deliver tangible results (Braniff 2009: 554).

In the first decade of the $20^{\text {th }}$ century, the EU's policy on the Balkans moved from an agenda dominated by security issues related to the war and its legacies to one focused on the perspective of the Western Balkan states' accession to the European Union, regarding which there has been a formal political commitment on the part of all EU member states ever since the Thessaloniki Summit held in June 2003 (Rupnik 2011: 17). The EU thereby created the main instrument for the Western Balkans countries, the Stabilisation and Association Process (SAP), launched in 2000. The Stabilisation and Association Process is the name of the EU's comprehensive, strategic approach to the Western Balkan countries, fostering regional cooperation, political dialogue and economic development among regional countries (Delević 2007: 2-3). Socio-economic changes in the Western Balkans, as a set of young states and democracies, including Montenegro, have been encouraged by the process of European integration as the most important drivers of overall changes in the region (Djurović - Jačimović 2014: 13-14).

Bearing in mind the experiences with the fifth round of enlargement, in December 2006 the European Council agreed on a new consensus on enlargement. Thus, all future enlargements of the Union would be subject to a more detailed pre-accession dialogue and more complex negotiation process. The process already becomes more complex in the battle for candidate country status, which means a country must be 'prepared beforehand' for the obligations deriving from membership. The accession process and accession negotiations are thereby becoming more complicated and demanding. We may talk about a new trend in the EU's enlargement policy - Enlargement Plus (Djurović - Milović 2013: 333). After Croatia joined the EU in 2013 and regional markets were opened up to EU companies, relations with the Western Balkan countries became a unique mix of stabilisation, democratisation and accession through the conditionality and socialisation instruments.

\section{Three generations of reforms and EU candidate status}

In the case of Montenegro, like in other parts of the ex-Yugoslav economic space, the transition started with a period of economic recession. In other words, unlike the Central and Eastern European countries, following a number of negative events, the transition in the former Yugoslav countries became a process of country dissolution and disintegration of the single market, finally resulting in war in Croatia and Bosnia and Herzegovina. The founding of the SRY in April 1992 was followed by UN economic sanctions up until September 1995, a block- 
ade of international trade, hyperinflation, and a general decrease in economic activity in all sectors. Of all the former Yugoslav states, Montenegro was more seriously affected by the breaking up of the state and the lost Yugoslav market for its exports as it was traditionally oriented to producing raw materials and importing final products from the then single Yugoslav market with a population of 23 million (Djurović - Radović - Djurašković 2011: 14). The mentioned dissolution of Yugoslavia and all associated problems meant the SRY found itself in a period of survival, a 'transition recession', while between 1990 and 1996 it experienced the most difficult economic and social crisis in recent history.

In an attempt to protect its basic economic resources, Montenegro started to gradually build its own economic system, including the design of its own economic policy. In July 1999, Montenegro adopted some regulations of a transitional character and stopped transferring some of its customs revenues to the federal budget, along with some of its sales tax and excise duty revenues. Montenegro then soon took charge of the customs service for its territory. Parallel to this, in November 1999 Montenegro introduced a dual currency system. Consequently, in November 2000 only the German mark remained the official currency in the payment system (Djurović - Muhadinović 2016: 521). After unilaterally introducing the German mark in 1999 after the economic crisis of the 1990s and the hyperinflation consequences, Montenegro established its own Central Bank of Montenegro, its own foreign trade and customs policy. In these exceptional circumstances, Montenegrin authorities adopted the euro as the country's official currency in 2002 (Djurović 2012: 243-244). The above mentioned were all initial steps for achieving macroeconomic stability after the transitional recession. The fight for independence in economic governance gradually became the path to regaining independence. The Republic of Montengro became part of the Federal Republic of Yugoslavia, which officially existed from April 1991 to February 2003, which was followed in the next 3 years by the State Union of Serbia and Montenegro. Montenegro again became an independent country after a referendum held on 21 May 2006.

The first phase of the real transition and first generation of reforms actually began with the monetary reform and by taking over powers in the fields of foreign trade and customs policy. It continued with the dynamic price liberalisation of the internal market, a reduction of customs and non-tariff barriers, the establishing of a significant number of new institutions, the adoption of strategic documents in key policy areas, which amounted to the approval of a set of new regulations in the fields of financial policy, customs, tax, and sectoral policy. More than $80 \%$ of the state's capital became privately-owned property through different privatisation models. In addition, the period of gradual economic recovery was followed by steady FDI growth. The first three years after regaining independence may be characterised by extraordinary economic dynamics: the average real GDP growth rate from 2006 to 2009 was 9\%, the average net 
FDI as a share of GDP I 2006-2009 was 25\% (Central Bank of Montenegro 2020). This was a period of gradually strengthening Montenegro's economic independence, as confirmed by the will of its citizens at a referendum held in May 2006. Its European orientation was then affirmed in October 2007 when the Stabilisation and Association Agreement was signed.

Having completed the first generation of reforms (privatisation, internal price and foreign-economic liberalisation, macroeconomic stabilisation), Montenegro successfully implemented the second generation of reforms, which address the following: completing its own legal system, establishing efficient and effective market institutions, and coordination of economic policies (Djurović Radović - Djurašković 2011: 16). The third generation of reforms may be defined as the process of European integration and the Montenegrin economy's substantial growth in competitiveness in response to the challenges of the economic crisis (Montenegrin GDP contracted by $5.7 \%$ in 2009, grew by $2.5 \%$ and $3.2 \%$ in 2010 and 2011, respectively; it contracted again in 2012 by $2.5 \%$; the average real growth rate between 2006 and 2019 was 3.3\%) (Monstat 2020). Opening of the economy, the liberalisation of foreign flows, rapid growth of different economic sectors, low inflation rate, even a budget surplus, strong FDI inflows, continuous reduction of the unemployment rate, lower external debt and a high trade deficit are all basic characteristics of the Montenegrin economy in the mentioned period. The business environment gradually became more attractive to investors, while economic relations were also strengthened, especially with the EU.

The relationship between Montenegro and the EU has been constantly developing. The signing of the Stabilisation and Association Agreement (SAA) on 15 October 2007 in Luxembourg denotes the start of the first contractual relationship with the EU. Political dialogue between Montenegro and the EU was launched by virtue of a government decision on 31 August 2006, when the Joint Declaration of Montenegro and the EU on establishing regular political dialogue was adopted. The first meeting of the Council for Stabilisation and Association, held on 14 June 2010 in Luxembourg, initiated a new form of cooperation - dialogue on association with Montenegro. Sustained by a general political consensus and high level of support for EU membership, Montenegro submitted its application for EU membership on 15 December 2008. This membership application initiated a set of comprehensive internal reforms and intensive preparations for the opening of accession negotiations that resulted in the adoption of a 5-year National Programme for the Integration of Montenegro with the EU on 5 June 2008. The European Commission issued an Opinion on Montenegro's application for membership on 9 November 2010, stating that Montenegro was a functional democracy with stable institutions guaranteeing the rule of law and a functional market economy. The European Commission recommended the Council give candidate-country status to Montenegro 
whereas the date of opening of the accession negotiations was to depend on the success in meeting recommendations in seven key areas identified in the Commission's opinion. Pursuant to the EC Opinion, the European Council gave of candidate status to Montenegro on 17 December 2010 and made its decision conditional on the opening of accession negotiations after having fulfilled the seven key priorities. On 12 October 2011, the European Commission published the Progress Report for Montenegro for 2011 in which it recommended opening up accession negotiations with the EU. The European Council concluded on 29 June 2012 that accession negotiations with Montenegro should be initiated and convened the first Intergovernmental Conference between Montenegro and the European Union with a view to the negotiations' formal beginning (Government of Montenegro 2012: 2-3).

\section{Accession negotiations with the EU: 8 years of learning lessons}

Following the restoration of independence after the referendum on 21 May 2006, as an independent country Montenegro has regarded joining the EU and NATO as its key strategic foreign policy priorities. NATO membership was achieved in June 2017, while the EU accession talks started in June 2012 with a very uncertain date for accession. After 8 years of accession talks, 32 (out of 35) negotiating chapters have been opened and 3 have been closed temporarily (chapters related to Science and research, Education and culture, and External relations).

Montenegro became an associated member of the EU when the SAA entered into force on 1 May 2010. The country uses the SAA mechanisms in its preparations for EU membership, thus providing for complementarity of the negotiations and the SAA framework in meeting the commitments undertaken. Montenegro actively participates in regular political dialogue with the EU on bilateral and international matters of mutual interest and promotes common positions in different areas of the Common Foreign and Security Policy, including the development of good neighbourly relations (Government of Montenegro 2012: 4).

Thus far in the accession process, Montenegro has received 87 closing benchmarks, i.e. conditions to close negotiation chapters, in 28 negotiating areas. However, the backbones of the negotiation process are 83 interim benchmarks created exclusively for Chapter 23 (Judiciary and fundamental rights) and Chapter 24 (Justice, freedom and security). These chapters ensure an overall balance in the progress of the negotiations across the chapters. Item 25 of the General position of the EU for accession talks with Montenegro states that "should progress under these chapters significantly lag behind progress in the negotiations overall, and after having exhausted all other available measures, the Commission will on its own initiative or on the request of one-third of the Member States propose to withhold its recommendations to open and/or close other negotiating chapters, and adapt the associated preparatory work, as ap- 
propriate, until this imbalance is addressed" (Council of the EU 2012: 7). This chiefly explains why 2019 was, for the first time, a year without intergovernmental conferences and without any chapter being opened or closed.

Based on lessons learned mostly from the accession talks with Montenegro and Serbia, the Commission proposed a new methodology for future accession talks with Albania and North Macedonia. To strengthen the current accession process, in February 2020 the Commission set out a new methodology for accession negotiations in the region. It is based on four main principles: credibility, firm political steering, predictability for both sides, and more integration dynamics (European Commission 2020: 2-3). The revised methodology relies on the same criteria to join the EU (Article 49 of the TEU, the Copenhagen criteria, the Madrid criteria and the additional SAP conditions related to regional cooperation and good neighbourly relations) which are clear and do not change. Introduced novelties to be inserted in their negotiation positions are as follows: screening process in clusters of chapters to allow for faster opening; preparation of roadmaps for Chapter 23 and Chapter 24, but also roadmaps to strengthen democratic institutions, for public administration reforms and for closer links with Economic Reform Programmes; the possibility to update opening/closing benchmarks; re-opening of chapters; negotiation of the fundamentals will be opened first and closed last, and progress with these will determine the overall pace of the negotiations (linking all chapters with rule-of-law chapters through an enhanced balance clause: without fulfilment of the C23 \& C24 interim benchmarks, one cannot close any other economic chapter) etc.

\section{Conclusion}

This article presented selected aspects of the development and integration of Slovenia and Montenegro, their relationships with the EU, as well as their similarities and differences. The purpose of the article was to highlight developments in both countries and determine whether Slovenia, as ex-Yugoslav republic and an EU member state since 2004, can serve as a good example for Montenegro as it pursues European integration. The article's main finding is that the two countries should - due to their similar interests - collaborate more in both the political and economic spheres. Slovenia has over the last 30 years acquired considerable experience with its political and economic transition towards a competitive European economy, and substantial experience within the EU, i.e. 15 years of fully-fledged EU membership. This may serve as a productive platform for Montenegro and allow it - based on the Slovenian experiences to avoid certain mistakes made by Slovenia during its EU accession process.

Since the dissolution of socialist Yugoslavia, the experiences of Slovenia and Montenegro with European integration have varied and today different challenges are continuing with respect to the EU - Slovenia as a member and 
Montenegro as a candidate. After 15 years of EU membership, it seems that EU affairs in Slovenia are slowly more acknowledged also at home. The Slovenian public is mostly interested in the role played by Slovenia in the EU and calling for a more active role. Based on the historic memory where Slovenia and its citizens have over the ages been subordinated to other bigger political structures, many citizens are hoping for a more important role in Europe. However, the recent period of Slovenian EU membership may be characterised as the absence of clear goals for Slovenia within the European integration. It seems that in the EU context Slovenia lacks visions and ambitions concerning its role. Domestic circles have been critical of this lack of political orientation since this has also added to the passive role being played by Slovenia and its political actors in the EU. There is thus far no sign this situation will improve as Slovenia is continuing with its 'policy' of no clear strategy in the EU, even though its goal of presenting itself as being committed to the idea of a united Europe remains. In the past, some attempts to be more proactive were even made. For example, after Jean Claude Juncker presented five possible scenarios for the EU's development, Slovenia expressed its strong ambition to remain in the circle of more integrated member states. At the beginning of 2017, some Slovenian intellectuals even wrote and signed the "Ljubljana initiative" to commence the process of adopting a new EU Constitution with the aim to protect the European idea and codify all of its dimensions within it. This initiative was also supported by Slovenian President Borut Pahor (MMC 2017), yet it has remained ignored in the EU context.

On the other hand, the result after two decades of the Stabilisation and Association process in the post-Yugoslav region is modest: only Croatia is an EU member state, Montenegro has been negotiating for 8 years, Serbia for 6 years, while North Macedonia and Albania entered the negotiations only at the end of March 2020, Bosnia and Herzegovina is hardly paving its way towards candidate status, and Kosovo is merely waiting for visa liberalisation. Despite the slowdown in the EU integration dynamic in recent years, support for EU membership in Montenegro is stable and exceeds $60 \%$ in almost all surveys. The country is entering a crucial phase of the integration process with a focus on the rule of law and the functioning of key democratic institutions important for meeting the main political accession criteria (areas of electoral legislation and trust in institutions, law on religious freedom and its implementation, media freedom, joint efforts to strengthen cohesion elements within the divided society etc.). It is extremely important to build greater trust among all stakeholders and political actors and to enhance dialogue about the accession process and make it more effective. The EU integration process must become more predictable, more credible - based on objective criteria and rigorous positive and negative conditionality - more dynamic and subject to greater political steering (European Commission 2020: 2-3). Only in this context is the future 
of Montenegro within the EU possible and may be seen as confirmation of the country's chosen development strategy.

Finally, changing European integration itself must be considered. The EU is not the same as it was over 15 years ago when it was first enlarged to post-socialist Eastern Europe. Moreover, in this period, Brexit means it has lost one member-state, while the integration also experienced two great crises - the 2008 economic and fiscal crisis and the 2015 migration crisis. Besides, the start of 2020 was marked by the COVID-19 pandemic health crisis, almost simultaneously also triggering a new economic crisis. All of these crises present the EU with several major challenges, including the uncertainty about the future physiognomy of the EU as a whole, and in particular the visions of future enlargement of the EU.

\section{References}

Adamović, Ljubiša (1988): Hronologija odnosa SFRJ-EEZ 1962-1986, in Adamović, Ljubiša, ed., Jugoslavija i EEZ, Institut za međunarodnu politiku i privredu, Beograd.

Ágh, Attila (2003): Anticipatory and Adaptive Europeanization in Hungary, Hungarian Centre for Democracy Studies.

Balažic, Milan (2002): Evropa zdaj. Teorija in praksa 39 (4): 559-578.

Braniff, Maire (2009): Transforming the Balkans? Lesson learning and institutional reflexivity in the EU enlargement approach. European Foreign Affairs Review 14: 547-563.

Burson Cohn \& Wolfe (2019): European Commission Scoreboard 2014-2019: available at: http:// europedecides.eu/wp-content/uploads/2019/02/EC_scoreboard_Report.pdf (19 October 2019).

Central Bank of Montenegro (2020): Statistical Database: available at: http://cbcg.me/index. php?mn1=statistika (22 February 2020).

Commission of the European Communities (1970): Information Memo, Brussels, March 1970: available at: http://aei.pitt.edu/30058/1/P_14_70.pdf (22 February 2020).

Delević, Milica (2007): Regional cooperation in Western Balkans. Chaillot Paper, 104, EUISS, July 2007.

Djurović, Gordana - Jačimović, Danijela (2014): From Stabilisation and Association Process to Full Membership of Western Balkans Countries - Case Study Montenegro. International Journal of Information Systems and Social Change 5 (3).

Djurović, Gordana - Milović, Nikola (2013): EU Enlargement Policy Framework for the Western Balkans: Six "C" Principles and the New Negotiating Rules. Economic integration, competition and cooperation, Proceedings, 17-19 April 2013, Opatija, Croatia.

Djurović, Gordana - Muhadinović, Milica (2016): Waiting for integration - going beyond transition: Case study Montenegro. Proceedings of International Conference: Researching Economic 
Development and Entrepreneurship in Transition Economies: Assessment of the last 25 years, going beyond the 'transition', REDETE 2015, University of Banja Luka.

Djurović, Gordana - Radović, Milivoje - Djurašković, Jovan (2011): Makroekonomske performance crnogorske privrede u periodu 2001-2010, Ekonomski razvoj kroz prizmu preduzetništva. Ekonomski fakultet, Podgorica, 19 May 2011.

Djurović, Gordana (2012): Evropska unija i Crna Gora: politika proširenja, Ekonomski fakultet, Podgorica.

ECHA, BAC (1980): European Commission Historical Archives, Brussels Archive Commission 25/1980/429/1, Report on exploratory talks with a Yugoslav delegation, Brussels, 4 February 1965.

ECHA, BAC (1986a): European Commission Historical Archives, Brussels Archive Commission 97/1986/2, Note on the attitude of the Six towards Yugoslavia's declarations, Brussels, 26 October 1962.

ECHA, BAC (1986b): European Commission Historical Archives, Brussels Archive Commission 97/1986/2, Meeting of the Council of Ministers, Brussels, 3-5 December 1962.

European Commission (2020): Communication from the Commission to the European Parliament, The Council, The European Economic and Social Committee and the Committee of the Regions, Enhancing the accession process - A credible EU perspective for the Western Balkans, Brussels, 5. 2. $2020 \operatorname{COM}(2020) 57$ final.

European Community (1980): News, No. 12/1980, 26 February 1980, Brussels: available at: http:// aei.pitt.edu/59648/1/EC_News_12.80.pdf (22 February 2020)

European Council on Foreign Relations (2018): EU Coalition Explorer: Results of the EU28 Survey 2018 on coalition building in the European Union: available at: https:/www.ecfr.eu/page/ ECFR269_EU_COALITION_EXPLORER_2018_V1. 10.pdf (19 October 2019).

Fink Hafner, Danica - Deželan, Tomaž (2016): Slovenia, in Viola, Donatella M., ed., Routledge Handbook of European Elections, 471-490, Routledge, London and New York.

Fink Hafner, Danica - Lajh, Damjan - Krašovec, Alenka (2005): Politika na območju nekdanje Jugoslavije, Fakulteta za družbene vede, Ljubljana.

Fink Hafner, Danica - Lajh, Damjan (2003): Managing Europe from Home: the Europeanisation of the Slovenian Core Executive, Faculty of Social Sciences, Ljubljana.

Fink Hafner, Danica - Lajh, Damjan (2005): Proces evropeizacije in prilagajanje političnih ustanov na nacionalni ravni, Fakulteta za družbene vede, Ljubljana.

Fink Hafner, Danica - Lajh, Damjan (2008): The 2008 Slovenian EU Presidency: A New Synergy for Europe? SIEPS, Stockholm.

Fink Hafner, Danica (1999): Dilemmas in Managing the Expanding EU: The EU and Applicant-States' Point of View. Journal of European Public Policy 6 (5): 783-801.

Fink Hafner, Danica (2007) Europeanization in Managing EU Affairs: Between Divergence and Convergence, a Comparative Study of Estonia, Hungary and Slovenia. Public Administration 85 (3): 805-828. 
Government of Montenegro (2012): General Position of the Government of Montenegro for Ministerial Meeting opening Intergovernmental Conference on Accession of Montenegro to the European Union, Podgorica, 29 June 2012.

Haček, Miro (2016): Slovenia: Country Profile, New York, Washington: Freedom House. Available at: https://freedomhouse.org/report/nations-transit/2016/slovenia (19 October 2019).

Héritier, Adrienne (1999): Policy-Making and Diversity in Europe. Escape from Deadlock, Cambridge University Press.

Jacobsen, Hanns D. (1997): The European Union's Eastward Enlargement, European Integration online Papers (EloP), 1(14): available at: http://eiop.or.at/eiop/texte/1997-014.htm (19 October 2019).

Krašovec, Alenka - Kustec Lipicer, Simona (2008): Euroscepticism and Slovenian Political Parties: A Case of Weak Party-based Euroscepticism, in Szczerbiak, Aleks - Taggart, Paul, eds., Opposing Europe: The Comparative Party Politics of Euroscepticism, 314-327, Oxford University Press.

Krašovec, Alenka - Lajh, Damjan (2004): The Slovenian EU Accession Referendum: A Cat-and-Mouse Game. West European Politics 27 (4): 603-623.

Krašovec, Alenka - Lajh, Damjan (2009): The European Union: A Joker or Just an Ordinary Playing Card for Slovenian Political Parties? The Journal of Communist Studies and Transition Politics 25 (4): 491-512.

Krašovec, Alenka - Lajh, Damjan (2020): Slovenia, in Hloušek, Vit - Kaniok, Petr, eds., The European Parliament Elections of 2019 in East-Central Europe, 253-275, Palgrave Macmillan, Cham.

Lajh, Damjan - Krašovec, Alenka (2007): Post-Yugoslav Region between Democratisation and Europeanisation of Party Politics: Experiences from Slovenia and Bosnia-Herzegovina. Politics in Central Europe 3 (1+2): 71-91.

Lajh, Damjan - Krašovec, Alenka (2010): Slovenia, in Mootz, Lisa, ed., Nations in Transit 2010: Democratization from Central Europe to Eurasia, 495-510, Freedom House, Rowman and Littlefield.

Lajh, Damjan (2005): Responses to the Processes of Europeanisation and Regionalisation: Domestic Changes in Slovenia. Perspectives 23: 36-60.

Lajh, Damjan (2012): Twenty Years of Relations between the Republic of Slovenia and the European Union. Studia Historica Slovenica 12 (1): 125-146.

Lajh, Damjan (2013): Slovenia, in Habdank-Kolaczkowska, Sylvana, ed., Nations in Transit 2013: Democratization from Central Europe to Eurasia, 535-552, Freedom House, Rowman and Littlefield.

Lajh, Damjan (2014): Slovenia, in Habdank-Kolaczkowska, Sylvana, ed., Nations in Transit 2014: Democratization from Central Europe to Eurasia, Freedom House, Rowman and Littlefield.

Lippert, Barbara - Umbach, Gaby - Wessels, Wolfgang (2001): Europeanization of CEE Executives: EU Membership Negotiations as a Shaping Power. Journal of European Public Policy 8 (6): 980-1012.

Lovec, Marko (2017): Slovenia: Country Profile, Freedom House: available at: https://freedomhouse.org/report/nations-transit/2017/slovenia (19 October 2019). 
Lovec, Marko (2018): Slovenia: Country Profile, New York and Washington, Freedom House: available at: https://freedomhouse.org/report/nations-transit/2018/slovenia (19 October 2019).

MEPranking (2019): available at: http://www.mepranking.eu/ (19 October 2019).

MMC (2017): Podpisana Ljubljanska pobuda za novo ustavo EU-ja, ki bi zavarovala evropsko idejo, 6 January 2017: available at: https://www.rtvslo.si/evropska-unija/podpisana-ljubljanska-pobuda-za-novo-ustavo-eu-ja-ki-bi-zavarovala-evropsko-idejo/411809 (19 October 2019).

Monstat (2020): Statistical Office of Montenegro, National Accounts Data, GDP: available at: https://www.monstat.org/eng/index.php (22 February 2020).

Montanari, Marco (2005): EU trade with the Balkans, large room for growth, Eastern European Economics 43 (1): 59-81.

Nations in Transit (2003): Slovenia, in: Nations in Transit 2003, Freedom House, Rowman and Littlefield: available at: https://freedomhouse.org/report/nations-transit/2003/slovenia (19 October 2019).

North, Douglass C. (1990): Institutions, Institutional Change and economic Performance, Cambridge University Press.

Obadić, Ivan (2014): A Troubled Relationship: Yugoslavia and the European Economic Community in Détente. European Review of History: Revue Europeenne d'histoire 21 (2).

Ramet, Sabrina P. (2002): Balkan Babel. The Disintegration of Yugoslavia from the Death of Tito to the Fall of Milosević, Westview Press.

Risse, Thomas - Cowles, Maria, G. - Caporaso, James, (2001): Europeanization and Domestic Change: Introduction, in Cowles, Maria G. - Caporaso, James - Risse, Thomas, eds., Transforming Europe. Europeanization and Domestic Change, 1-20, Cornell University Press.

Rupnik, Jacques (2011): The Balkans as a European Question, in Rupnik, Jacques, ed., The Western Balkans and the EU: The Hour of Europe, Chaillot Paper, 126, EUISS, June 2011.

Štiks, Igor (2011): The European Union and Citizenship Regimes in the Western Balkans, in Rupnik, Jacques, ed., The Western Balkans and the EU: The Hour of Europe, Chaillot Paper, 126, EUISS, June 2011.

The Council of the EU (2012): European General EU position, Ministerial meeting opening the Intergovernmental Conference on the Accession of Montenegro to the European Union (Brussels, 29 June 2012), AD 23/12, CONF-ME 2.

Zaccaria, Benedetto (2016): The EEC's Yugoslav Policy in Cold War Europe, 1968-1980, Palgrave Macmillan.

Zorman Macura, Janja (2019): Posebni vladni projekt: Predsedovanje Republike Slovenije Svetu Evropske unije 2021. Projektna naloga. Republika Slovenija: available at: https://www.gov. si/assets/vlada/Projekti/PSEU2021/Predsedovanje_Svetu_EU_-_projektna_naloga.pdf (19 October 2019).

Gordana Djurovic is a Professor at the Faculty of Economics, University of Montenegro, Podgorica, Montenegro and president of the Montenegrin Pan-European Union. Her research interests include EU enlargement policy, international economic 
relations, EU cohesion policy, sustainable development and economic development of Montenegro. E-mail address: gordana@ucg.ac.me.

Damjan Lajh is associate professor of policy analysis at the University of LjubljanaFaculty of Social Sciences, Jean Monnet Chair, Head of the Centre for Political Science Research, coordinator of Master Study in Political Science - Policy Analysis and Public Administration, and academic coordinator of the University of Ljubljana Jean Monnet Centre of Excellence. His research interests encompass public policies and policymaking processes in the national and EU context, Europeanization processes, interest groups and lobbying, and new forms of governance in the EU. E-mail address:damjan.lajh@fdv.uni-lj.si. 